\title{
Biographical Sketch of Joseph D. McCutchan
}

Joseph D. McCutchan, ${ }^{1}$ adventurer, soldier, amateur poet, merchant, lawyer, and judge, was born July 18,1823 , in Wilson County, Tennessee, ${ }^{2}$ later moving to Carroll County, Mississippi, where in 1839 he joined the Presbyterian church and, thereafter, was known to be a faithful member of that religious organization and a devoted Christian.

From Mississippi, in company with his brother William H. McCutchan, some eight years his senior, he emigrated to Texas by way of New Orleans, passing out of the mouth of the Mississippi River at night late in December $1840,{ }^{3}$ and arriving at Galveston early in January I 84I. The two brothers soon settled in Washington County.

When the Mexican raids upon San Antonio began in 1842, Joseph D. McCutchan affiliated with the local militia organization. On October 17,1842 , at the age of nineteen, he was enrolled as a second lieutenant in Captain William P. Rutledge's company and went with that company to San Antonio. Upon the organization of the troops in the vicinity of San Antonio on November 7, 1842, into the First Regiment of the South Western Army, Captain Jerome B. Robertson was elected to command the company; however, McCutchan continued to serve as second lieutenant of the company and was mustered into the South Western Army of Operations under the command of Brigadier General Alexander Somervell on November 2I, I842, by Robert H. Dunham, brigade inspector. ${ }^{4}$

All of the effective units of militiamen of the counties of Matagorda, Fayette, Victoria, Brazoria, Fort Bend, Austin, Colorado, Gonzales, Bastrop, Montgomery, and Washington had been ordered to San An-

I. The name McCutchan has been spelled variously-McCutcheon, McCutchings, and McCutchan-but all evidence seems to indicate that the man himself wrote it as McCutchan. In reporting the donation of the diary to the Texas Historical Society of Galveston, the Galveston News, Feb. 7, I875, p. 2, gave the name as James D. McCutchings.

2. M. Yell to editor of the Texas Ranger and Lone Star, June 9, 1853, p. 2; McCutchan's diary, July 18,1844 .

3. McCutchan's diary, Nov. 4, I844.

4. Copy of Muster Roll of Jerome B. Robertson's company, First Regiment of South Western Army, in Sam S. Smith Collection, Archives, University of Texas; Joseph Milton Nance, Attack and Counterattack, pp. 445, 478, 643644 . 
tonio to repel the Mexican invader. Before the arrival of these forces, however, Texas volunteers rallying under the leadership of Colonel Mathew Caldwell had repulsed the Mexican invading force under General Adrián Woll and forced its retirement from Texas.

President Sam Houston on October 3 named Brigadier General Alexander Somervell, who commanded the militia forces west of the Trinity River, to take command of the troops concentrating in the San Antonio area. If upon reaching the southwestern frontier Somervell should conclude that he could advance with success into the enemy's territory, he was to do so immediately. But, also, it was emphasized that the troops must be well disciplined, subordinate and obedient to his orders, and willing to cross the Rio Grande if ordered to do so. The full story of the Somervell Expedition to the Rio Grande in November and December, 1842 , resulting in the Texan capture of Laredo and Guerrero, has been told. ${ }^{5}$

Following the capture of Guerrero, as the Texan army lay on the east side of the Rio Grande opposite the town, those of the Somervell Expedition who did not wish to return home without having both chastized the enemy and obtained suitable mounts and provisions for the return journey urged Somervell to prosecute the campaign further. When he refused to do so, they sought permission to separate from the command with the idea of continuing the march down the river. Again, Somervell refused to accede to their request; whereupon, 305 dissatisfied officers and men withdrew from the command on December 19,1842 , to carry on a private war of their own. ${ }^{6}$ McCutchan had earlier withdrawn from Robertson's company on December II to join that of Captain William S. Fisher as a private. When Fisher was elected on the nineteenth to command what came to be known as the Mier Expedition, Claudius Buster was chosen to command the company. Fisher was accorded the rank of "colonel."

McCutchan was among those who surrendered at Mier on the afternoon of December 26, I842, to the forces under General Pedro de Ampudia. In his report of the battle of Mier, General Ampudia listed McCutchan's occupation as printer. ${ }^{7}$

From Mier the Texan prisoners were taken to Matamoros and

5. Nance, Attack and Counterattack, pp. 427-578.

6. Memucan Hunt to Francis Moore, Jr., editor of the Telegraph, [dated] Bexar, Jan. 8, 1843, in Morning Star, Jan. 17, 1843; McCutchan's diary, p. 32; Thomas Jefferson Green, Journal of the Texian Expedition against Mier, p. 66. Green says 304 men separated from Somervell's command.

7. Pedro de Ampudia to Ministro de Guerra, José María Tornel, [dated] Mier, Dec. 29, 1842, in El Cosmopolita, Jan. 25, 1843, pp. 2-3. 
from there were ordered to Mexico City. As the prisoners prepared to leave Matamoros on January I4, I843, the complaint was made that several of the men were too ill to travel. The Mexican surgeon general of the post was sent to examine them, and he reported that six of the prisoners, including McCutchan, were unable to travel. These men and three boys of the expedition were retained at Matamoros, and at the end of nine weeks were joined by several of their comrades who had been left wounded at Mier. About March I ten of the Texan prisoners at Matamoros were sent on the route via Monterey toward Mexico City, and on March II McCutchan and four others were dispatched along the route via Tampico and Real del Monte to Mexico City. McCutchan and his companions arrived at Mexico City on May 27 and three days later joined the main body of prisoners at Tacubaya, where their comrades were working to improve the road that ran from the town of Tacubaya to the Archbishop's Palace, the residence of President Antonio López de Santa Anna, which was situated at a distance of several hundred yards from the city.

On September 5, 1843, Santa Anna's secretary announced that the road had been completed, and the prisoners were returned to the Convent Santiago, where they had earlier been imprisoned, preparatory to being transferred to the Castle of San Carlos de Perote, on the road between Mexico City and Vera Cruz.

The prisoners reached Perote Castle on September 2I. Four days later an epidemic of typhus (thought at first to have been jail fever) struck the prisoners, and eventually all but three of the Mier men suffered from its attack. More than a few died and were buried in the moat that surrounded the castle. McCutchan was one of the first to fall victim to the epidemic, which caused him to be hospitalized for thirty days, and "for fourteen of that time [he was] entirely insensible to all earthly things, even to suffering itself."

After undergoing many unbelievable hardships, experiencing cruel treatment, and suffering woefully inadequate food and clothing, the last of the Mier prisoners were released on September I6, I844, after an imprisonment of twenty months and twenty-one days. Most of them headed home to Texas as quickly as transportation could be obtained. They reached New Orleans on November 4 and from there went to Galveston aboard the New York.

As McCutchan landed at Galveston on November Io, he was, like most of his companions, destitute and downhearted because there was no royal welcome or spread of a red carpet for the returning "heroes" from the dungeons of Mexico. Then all of a sudden he saw approach- 
ing his brother William $\mathrm{H}$., who had heard of the arrival of the prisoners and had hastened to the wharf. It was a heart-warming greeting, and Joseph recalled the experience in his diary: "Then I was at Home in the complete sense of the word." ${ }^{8}$ Finally, on October $3 \mathrm{I}$, I850, he received compensation from the state of Texas in the amount of $\$ 685.43$ for his services as a lieutenant (October I7 to December $\mathrm{II}, \mathrm{I} 842$ ) and as a private (December I2, I842 to October I6, I844) and for losses (one horse) on the Mier Expedition. His pay as a lieutenant was at the rate of $\$ 67.33$ per month and as a private at $\$ 22.00$ per month. ${ }^{9}$

Soon after his return to Texas, McCutchan became involved with his brother and others in a variety of trade activities. By the fall of I 845 he had returned to Washington, and by December I845 the McCutchan brothers and J. Montgomery had established a partnership to engage in business as "cotton factors, commission merchants, and General Dealers in dry goods and groceries," and to "offer for sale in Houston, Harris County, and Brenham, Washington County, a full assortment of dry goods," ready-made clothing, and other articles of trade, including "first quality Kentucky bagging and rope." 10 Joseph D. was to manage the Brenham store, while his brother managed the one in Houston. Among other activities, Joseph D. McCutchan in I848 was the agent for the Galveston Weekly News in Washington County. In the I85os William $\mathrm{H}$. McCutchan owned a steam sawmill at Longpoint, but whether his brother was involved in this particular operation is not known.

On October 25, I845, Joseph McCutchan acquired from Jesse Farral and James Hunt, of Washington County, for \$roo two and one-eighth acres of land on New Year's Creek in the Arabella Harrington League about two and one-eighth miles from Brenham. ${ }^{11}$ In I85I Joseph McCutchan and McNight were engaged in the Santa Fe trade, with an agency at Santa Fe, New Mexico, ${ }^{12}$ but apparently McCutchan remained in Texas.

In August I847 both of the McCutchan brothers married. On August 9 marriage licenses were issued to J[oseph] D. McCutchan and Miss E[lizabeth] Hutchinson, daughter of Captain Burrel B. Hutchinson, and to William H. McCutchan and Miss Elizabeth Farquhar,

8. McCutchan's diary, Nov. Io, I844.

9. Joseph D. McCutcheon, Public Debt Papers (Texas), Texas State Archives. то. Telegraph and Texas Register, Dec. I0, I845-Feb. 4 , I846.

II. Deed Records, Washington County, Brenham, Texas, vol. G, pp. 35-37. Transaction was dated Oct. 25, 1845, and deed filed Oct. 27, 1845. I2. San Antonio Texan, quoted in Northern Standard, June I4, I851. 
daughter of James L. Farquhar. Joseph D. was married August I 8 and his brother, the next day. The Rev. John Lember was the minister who performed the ceremony of marriage for Joseph, and the Rev. B. B. Baxter did the same for William. ${ }^{13}$

On November I8, I847, Joseph D. McCutchan was received into the Presbyterian church in Washington, when the church was officially enrolled in the Brazos Presbytery. His wife, Elizabeth, was received into the same church by letter from the Methodist Episcopal Church South of Washington on May $23,1848 .{ }^{14}$

By 1849 McCutchan had moved to Springfield, Limestone County, where he was an attorney-at-law. ${ }^{15}$ A public meeting was held on June 2, I849, at Springfield to promote the selection of a site east of the Brazos River for the state capital. The Constitution of 1845 had called for a special election to be held in 1850 to locate the state capital for twenty years. Joseph D. McCutchan was called to the chair and James M. Davis was appointed secretary of the meeting. The meeting at Springfield had been prompted by a call of the citizens of Palestine for a meeting of representatives from the eastern counties of the state at Palestine on July 4, 1849. The June 2 meeting requested the citizens of Limestone County to meet in a county convention at Springfield on June ${ }^{4} 4$ to choose delegates to the Palestine convention. ${ }^{16}$ Upon meeting, the convention recommended Springfield as the site for the state capital because of its climate, water, and other considerations, including the fact that it was near the geographic center of the inhabited area of the state. Three weeks later, the convention at Palestine recommended Springfield as the site for the seat of government.

In January I 850 while living in Limestone County, McCutchan sold his small tract of land on New Year's Creek, on which he had built a home and made other improvements, for \$I,050 to Patrick H. Lusk, who had been a member of the Mier expedition and was then living in Washington County. ${ }^{17}$ The year 1850 marks the first United States census taken in Texas. It shows that McCutchan's wife, Elizabeth, had

I3. W. Broadus Smith, Marriage Records, Washington County, Texas, pp. 24-25.

I4. Washington Presbyterian Church Minutes, I846-I888, pp. 2 and 6, Archives, University of Texas.

15. Ray A. Walter, A History of Limestone County, p. 30; V. K. Carpenter, (transcriber), The State of Texas Federal Population Schedules, Seventh Census of the United States, I850, item no. 222.

16. Northern Standard, July I4, 1849.

I7. Deed Records, Washington County, vol. IJ, p. I92; transaction dated Jan. I4, I850, and deed filed Feb. 22, I850. 
been born in Alabama and was in I850 nineteen years of age, that Joseph D. was twenty-seven years old, and that they were the parents of one child, a son (Joseph D.), age one month. ${ }^{18}$ The census also lists McCutchan's occupation as attorney-at-law.

In the elections in Limestone County for county and district officers on August 5, 1850, McCutchan was a successful candidate for the office of chief justice of the county. ${ }^{19}$ A year later, he was chosen to represent the Twenty-seventh Representative District of Limestone and Navarro to the House of Representatives of the Fourth Legislature of the State of Texas over General Edward H. Tarrant by a majority of twelve votes. ${ }^{20}$ When the legislature met on November 3, I85 $\mathrm{I}$, and organized, however, Tarrant contested the election, and the House of Representatives ordered its Committee on Privileges and Elections to investigate the matter. The committee made its report on November $6{ }^{21}$ It found that Tarrant had actually received 476 votes to 423 for McCutchan, making, it said, a majority of forty-seven votes in favor of Tarrant; ${ }^{22}$ and the committee, therefore, declared that General Tarrant had been elected, although the chief justice of Limestone County (McCutchan) had given the certificate of election to McCutchan. It found that the vote of Tarrant County, which was attached to the District of Limestone and Navarro, had not been submitted to the judge by the required date for submission and therefore had not been counted in the returns from the district. The committee's report read:

Your committee cannot believe that it was the intention of the law, to deprive the free people of this county of their right of suffrage, or to exclude the Representative of their choice, from the rights and privileges conferred upon him by their votes, by a mere technicality, and such would be the case if Mr. Tarrant were not permitted to take his seat in this body. Had the vote of Tarrant County been received by the Chief Justice of Limestone before the certificate was given to Mr. McCutchan, no one can

18. Carpenter (transcriber), State of Texas Federal Population Schedules, I850, item no. 222.

19. Hampton Steele, A History of Limestone County, 1833-1860, p. 25.

20. Texas State Gazette, Sept. I3, I85 I.

21. Texas Legislature, Journals of the House of Representatives of the State of Texas, Fourth Legislature, pp. 19-20, 23; Northern Standard, Nov. 29, I $85 \mathrm{x}$.

22. The figures do not jibe. It is possible that the typesetter misread 470 to be 476 for Tarrant. 
imagine for a moment that the certificate would have been given, but on the contrary, the certificate of election would have been given to Mr. Tarrant. Should, then, the will of the people clearly expressed, as it has been on this occasion, be defeated by an irregularity of the mails, or by any other course over which they. had no control! Your committee think not. ${ }^{23}$

Thus General Tarrant was declared elected, although a portion of the votes had not been returned by the deadline set for reporting.

During the early I850s there was a strong influx of new settlers into Limestone County, and Springfield itself felt a significant growth in population. On August 2, I852, when the next election for county and district officers took place, McCutchan was a candidate for re-election to the office of chief justice and was successful in winning a second term. ${ }^{24}$

In March I853 McCutchan was again a candidate for public office. This time he sought the office of district attorney for the new Thirteenth Judicial District created by the last legislature, consisting of the counties of Limestone, Robertson, Leon, Falls, and Navarro. The election took place on Monday, March I $4 .{ }^{25}$ Opposing McCutchan of Springfield were Robert Simonton Gould of Centerville, Glover W. Barton of Wheelock, and Roger Q. Mills of Corsicana. Initial published returns on April 2 from Leon County (incomplete) showed Gould, I33 votes; McCutchan, 22 votes; Barton, I 8 votes; and Mills, Io votes. ${ }^{26} \mathrm{~A}$ week later the Texas State Gazette reported, that, although all returns were not yet in, there was little doubt but that Gould had been elected. ${ }^{27}$ Finally, on May 2I, the Texas State Gazette reported the official vote, as given in the Leon Pioneer, to show the election of Robert S. Gould with McCutchan coming in a poor fourth in a field of four candidates. ${ }^{28}$

Less than six weeks after the election for district attorney Joseph D.

23. Texas Legislature, Journals, House of Representatives, Fourth Legislature, pp. 19-20.

24. Steele, A History of Limestone County, pp. 25, 76.

25. Texas State Gazette, Mar. I9, I853.

26. Ibid., Apr. 2, 1853 .

27. Ibid., Apr. 9, I853, citing Leon Pioneer.

28. The final vote stood as follows: Robert S. Gould, 290; Roger Q. Mills, 287; Glover W. Barton, 277; and Joseph McCutchan, 198. The vote at Whitaker's box, Falls County, was not received in time to be counted. It stood as follows: Gould, 4 ; McCutchan, Iо; Barton, Iо. Texas State Gazette, May 2I, 1853 . 
McCutchan, following an illness of about four weeks, died on Sunday, April 24, I853 while yet in his twenty-ninth year. The editor of the Leon Pioneer described him as an "honest man, a good citizen and respected by all who knew him." ${ }^{29}$ Although he suffered much in his last illness from severe pain, he endured all "with Christian fortitude and frequently spoke of the goodness of God." ${ }^{30} \mathrm{He}$, and later his brother, were buried in "the old cemetery" two or three miles east of Burton. ${ }^{31}$

Of the many diaries and extensive accounts of the Mier Expedition written by the participants, Joseph D. McCutchan's diary adds much to the literature and to the portrayal of the feelings of the men involved in that episode in the history of the Republic of Texas. For one who had been in Texas less than two years before embarking upon a campaign against the country's remorseless enemy, a campaign that ended so disastrously, McCutchan's love, dedication, and devotion to Texas remained unchanged throughout his life.

29. Quoted in Texas State Gazette, May 2I, I853.

30. M. Yell to editor of the Texas Ranger and Lone Star, June 9, 1853.

3I. Worth S. Ray, Austin Colony Pioneers, p. 159. 